\title{
Differential effects of fluoxetine enantiomers in mammalian neural and cardiac tissues
}

\author{
JÁNOS MAGYAR ${ }^{1}$, ZOLTÁN RUSZNÁK ${ }^{1}$, CSABA HARASZTOSI ${ }^{1}$, ÁGNES KÖRTVÉLY ${ }^{1}$, \\ PÁL PACHER ${ }^{2,3}$, TAMÁS BÁNYÁSZ ${ }^{1}$, CSABA PANKUCSI ${ }^{1}$, LÁSZLÓ KOVÁCS ${ }^{1}$, \\ GÉZA SZÛCS ${ }^{1}$, PÉTER P. NÁNÁSI ${ }^{1}$ and VALÉRIA KECSKEMÉTI ${ }^{1}$ \\ ${ }^{1}$ Department of Physiology, University of Debrecen, Medical School, H-4012 Debrecen; \\ ${ }^{2}$ Department of Pharmacology and Pharmacotherapy, Medical Faculty, Semmelweis University of Medicine, \\ H-1445 Budapest, Hungary; ${ }^{3}$ Inotek Corporation, 100 Cummings Center, Suite 419/E, Beverly, MA 01915, USA
}

Received September 25, 2002; Accepted November 14, 2002

\begin{abstract}
Racemic fluoxetine is a widely used SSRI antidepressant compound having also anticonvulsant effect. In addition, it was shown that it blocked several types of voltage gated ion channels including neural and cardiac calcium channels. In the present study the effects of enantiomers of fluoxetine (R(-)-fluoxetine and $\mathrm{S}(+)$-fluoxetine) were compared on neuronal and cardiac voltage-gated $\mathrm{Ca}^{2+}$ channels using the whole cell configuration of patch clamp techniques, and the anticonvulsant action of these enantiomers was also evaluated in a mouse epilepsy model. In isolated pyramidal neurons of the dorsal cochlear nucleus of the rat the effect of fluoxetine $(\mathrm{S}(+), \mathrm{R}(-)$ and racemic) was studied on the $\mathrm{Ca}^{2+}$ channels by measuring peak $\mathrm{Ba}^{2+}$ current during ramp depolarizations. All forms of fluoxetine reduced the $\mathrm{Ba}^{2+}$ current of the pyramidal cells in a concentration-dependent manner, with a $\mathrm{K}_{\mathrm{d}}$ value of $22.3 \pm 3.6 \mu \mathrm{M}$ for racemic fluoxetine. This value of $K_{d}$ was higher by one order of magnitude than found in cardiac myocytes with fluoxetine enantiomers $(2.4 \pm 0.1$ and $2.8 \pm 0.2 \mu \mathrm{M})$. Difference between the effects of the two enantiomers on neuronal $\mathrm{Ba}^{2+}$ current was observed only at $5 \mu \mathrm{M}$ concentration: $\mathrm{R}(-)$-fluoxetine inhibited $28 \pm 3 \%$ of the peak current, while $\mathrm{S}(+)$-fluoxetine reduced the current by $18 \pm 2 \%(n=13, P<0.05)$. In voltage clamped canine ventricular cardiomyocytes both enantiomers of fluoxetine caused a reversible concentration-dependent block of the peak $\mathrm{Ca}^{2+}$
\end{abstract}

Correspondence to: Dr Péter Pál Nánási, Department of Physiology, University of Debrecen, Medical School, H-4012 Debrecen, P.O. Box 22, Hungary

E-mail: nanasi@phys.dote.hu

Key words: fluoxetine (Prozac) enantiomers, antidepressant drugs, anticonvulsant drugs, electrophysiology, pyramidal cells, ventricular myocytes, action potential duration, $\mathrm{Ca}^{2+}$ current, $\mathrm{Na}^{+}$current, epilepsy current measured at $0 \mathrm{mV}$. Significant differences between the two enantiomers in this blocking effect was observed at low concentrations only: $\mathrm{S}(+)$-fluoxetine caused a higher degree of block than R(-)-fluoxetine $(56.3 \pm 2.2 \%$ versus $49.1 \pm 2.2 \%$ and $95.5 \pm 0.9 \%$ versus $84.5 \pm 3.1 \%$ block with 3 and $10 \mu \mathrm{M} \mathrm{S}(+)$ and $\mathrm{R}(-)$-fluoxetine, respectively, $\mathrm{P}<0.05, \mathrm{n}=5)$. Studied in current clamp mode, micromolar concentrations of fluoxetine shortened action potential duration of isolated ventricular cells, while higher concentrations also suppressed maximum velocity of depolarization and action potential amplitude. This shortening effect was significantly greater in the case of $\mathrm{S}(+)$ than $\mathrm{R}(-)$-fluoxetine at 1 and $3 \mu \mathrm{M}$ concentrations, whereas no differences in their effects on depolarization were observed. In pentylenetetrazole-induced mouse epilepsy model fluoxetine pretreatment significantly increased the 60 min survival rate, survival duration and seizure latency. These effects were more pronounced with the R(-) than the $\mathrm{S}(+)$ enantiomer. The results indicate that fluoxetine exerts much stronger suppressive effect on cardiac than neuronal calcium channels. At micromolar concentrations (between 1 and $10 \mu \mathrm{M}) \mathrm{R}(-)$-fluoxetine is more effective than the $\mathrm{S}(+)$ enantiomer on neuronal, while less effective on cardiac calcium channels. The stronger anticonvulsant effect of the R(-) enantiomer may, at least partially, be explained by these differences. Used as an antidepressant or anticonvulsant drug, less severe cardiac side-effects are anticipated with the $\mathrm{R}(-)$ enantiomer.

\section{Introduction}

Fluoxetine is a widely used antidepressant compound, its action is primarily attributed to inhibition of the reuptake of serotonin (SSRI) in the central nervous system. Recent studies indicated, however, that fluoxetine had several additional effects, many of them involving inhibition of various types of ion channels, such as muscular and neuronal nicotinic receptors $(1,2)$, volume-regulated anion channels (3), delayed rectifier $\mathrm{K}^{+}$channels in smooth muscle cells (4), voltage-gated $\mathrm{Na}^{+}$ and $\mathrm{K}^{+}$channels in neurons $(5,6)$ and epithelial cells $(7)$, voltage-gated $\mathrm{Ca}^{2+}$ channels in cardiac myocytes (8), nerve terminals (9) and hippocampal pyramidal cells (10). 
Several reports indicated that some conventional antiepileptic drugs were found to inhibit $\mathrm{Ca}^{2+}$ channels (11-14), and vice versa, dihydopyridine type $\mathrm{Ca}^{2+}$ channel blockers were claimed to suppress epileptiform activity (15-18). Therefore, it is not surprising that fluoxetine was found to enhance the anticonvulsant potency of traditionally used antiepileptic drugs $(19,20)$, and moreover, the drug exerted franc anticonvulsant action in animal as well as human studies (21-25).

Beyond the antidepressant and anticonvulsive actions of fluoxetine discussed above, cardiovascular side-effects, like dysrhythmias, atrial fibrillation, bradycardia (26-33) and syncope (34-38) were reported in association with fluoxetine treatment and overdose in man. These cases appear to be due to the inhibitory action of fluoxetine on cardiac $\mathrm{Ca}^{2+}$ and $\mathrm{Na}^{+}$ channels (8).

In all of the cited studies and case reports racemic fluoxetine was applied. However, pharmacological properties of enantiomers of fluoxetine were recently published (39-41). The two enantiomers of fluoxetine were found to be nearly equipotent inhibitors of serotonin reuptake but $\mathrm{S}(+)$-fluoxetine was more slowly eliminated than the $\mathrm{R}(-)$ enantiomer $(39,40)$. Based on their different pharmacokinetic properties and an absence of central stimulant effect of $\mathrm{S}(+)$-fluoxetine, the $\mathrm{S}(+)$ enantiomer is currently developped as an antimigraine drug, while R(-)-fluoxetine was suggested for treatment of depression $(39,41)$. The goal of the present study was to compare the effects of fluoxetine enantiomers in suppression of neuronal and cardiac $\mathrm{Ca}^{2+}$ channels, and to study the two enantiomers separately in a mouse epilepsy model.

\section{Materials and methods}

Ion current measurements in cochlear neurons isolated from rat brain. The neuron isolation procedure was similar to that described earlier (42). Briefly, after the decapitation of the 5 to 11-day-old rat $(n=15)$ the brain was removed into ice-cold artificial cerebrospinal fluid (aCSF), where $\mathrm{Na}^{+}$was replaced by equimolar sucrose ('low sodium' aCSF). The normal aCSF contained: $125 \mathrm{mM} \mathrm{NaCl} ; 2.5 \mathrm{mM} \mathrm{KCl} ; 10 \mathrm{mM}$ glucose; $1.25 \mathrm{mM} \mathrm{NaH} \mathrm{PO}_{4} ; 26 \mathrm{mM} \mathrm{NaHCO} ; 2 \mathrm{mM} \mathrm{CaCl} ; 1 \mathrm{mM}$ $\mathrm{MgCl}_{2} ; 3 \mathrm{mM}$ myo-inositol; $0.5 \mathrm{mM}$ ascorbic acid; $2 \mathrm{mM} \mathrm{Na}$ pyruvate. Osmolarity of the aCSF solution was $335 \mathrm{mOsm} / \mathrm{l}$, and the $\mathrm{pH}$ was set to 7.2 by $\mathrm{NaOH}$. The dorsal cochlear nuclei were then removed and put into an incubation chamber containing normal aCSF, supplemented with $0.03 \mathrm{mg} / \mathrm{ml}$ collagenase (type IA, Sigma) plus $0.12 \mathrm{mg} / \mathrm{ml}$ pronase (type XIV, Sigma), for $50 \mathrm{~min}$ at $31^{\circ} \mathrm{C}$. The incubating solution was gassed with carbogen $\left(95 \% \quad \mathrm{O}_{2} / 5 \% \mathrm{CO}_{2}\right)$. The enzyme treatment was terminated transferring the tissue to normal aCSF containing $1 \mathrm{mg} / \mathrm{ml}$ trypsin inhibitor (type I-S, Sigma). Neurons were isolated by gentle trituration with fire-polished Pasteur pipette in HEPES buffered aCSF, containing: $135 \mathrm{mM}$ $\mathrm{NaCl} ; 3 \mathrm{mM} \mathrm{KCl} ; 10 \mathrm{mM}$ glucose; $10 \mathrm{mM}$ HEPES; $30 \mathrm{mM}$ sucrose; $2 \mathrm{mM} \mathrm{CaCl}_{2} ; 1 \mathrm{mM} \mathrm{MgCl}_{2}$. After dissociation, the cells were allowed to settle for $30 \mathrm{~min}$ prior to the experiments.

Recording of ion currents was performed at room temperature $\left(20-22^{\circ} \mathrm{C}\right)$. The isolated cells were visualized by using an inverted microscope (Nikon Diaphot 300, Japan) equipped with phase-contrast optics. Cells with triangular body were selected for the current study. Patch pipettes were fabricated from thick-walled borosilicate glass (BioLogic Science Products, Germany). The pipette resistance was 1.5-2 M $\Omega$ when filled with the pipette solution, containing: $145 \mathrm{mM}$ N-methyl-D-glucamine; $40 \mathrm{mM}$ HEPES; $4 \mathrm{mM}$ $\mathrm{MgCl}_{2} ; 5 \mathrm{mM}$ EGTA; $12 \mathrm{mM}$ phosphocreatinine; $2 \mathrm{mM}$ MgATP; $0.5 \mathrm{mM} \mathrm{Na}_{3} \mathrm{GTP}$ (type II-S). The $\mathrm{pH}$ of this solution was adjusted to 7.3 by application of $\mathrm{HCl}$. After the cells settled down and adhered to the bottom of the experimental chamber, the bath solution was changed to HEPES buffered aCSF supplemented with the following channel blockers to minimize the interfering currents: $1 \mu \mathrm{M}$ tetrodotoxin; $1 \mathrm{mM}$ $\mathrm{CsCl} ; 2 \mathrm{mM}$ 4-aminopyridine and $5 \mathrm{mM}$ TEA. In addition, the $\mathrm{Ca}^{2+}$ content of this solution was replaced by $5 \mathrm{mM} \mathrm{Ba}^{2+}$ in order to increase the amplitude of the ionic current flowing through the high-voltage activated $\mathrm{Ca}^{2+}$ channels. Thus, the charge carrier was $\mathrm{Ba}^{2+}$ when measuring currents through $\mathrm{Ca}^{2+}$ channels. When the effect of fluoxetine was investigated, fluoxetine was dissolved in the $\mathrm{Ba}^{2+}$ based extracellular solution described above, and this solution was applied with a gravitydriven perfusion system, similarly to the application of the control extracellular solution. The currents were recorded in the whole cell configuration of the patch clamp technique by using an Axopatch 200A amplifier connected to a TL-1 interface (Axon Instruments, CA). Data acquisition and analysis was achieved by the pClamp 6.0 software (Axon Instruments, $\mathrm{CA}$ ). Digitization rate was $5 \mathrm{kHz}$ and the current signals were filtered at $2 \mathrm{kHz}$ with a 4-pole Bessel filter. The capacitive transients were electronically compensated, while leak correction was performed by measuring the leak current evoked by small voltage steps from a holding potential of $-75 \mathrm{mV}$, and subtracting the extrapolated leak current from the total current. Series resistance varied between 2.5 and $17 \mathrm{M} \Omega$, and it was compensated by at least $40 \%$. No correction was made for the junction potential typically of 2-3 $\mathrm{mV}$.

Electrophysiological measurements in isolated canine ventricular myocytes. Single canine ventricular myocytes were obtained from hearts of adult mongrel dogs using the segment perfusion technique as described earlier (43). Briefly, the animals (10-20 kg) were anesthetized with i.v. injection of $10 \mathrm{mg} / \mathrm{kg}$ ketamine hydrochloride (Calypsolvet) plus $1 \mathrm{mg} / \mathrm{kg}$ xylazine hydrochloride (Rometar). After opening the chest the heart was rapidly removed and the left anterior descending coronary artery was perfused using a Langendorff apparatus. $\mathrm{Ca}^{2+}$-free JMM solution (Minimum Essential Medium Eagle, Joklik modification; Sigma, product no. M0518), supplemented with taurine $(2.5 \mathrm{~g} / \mathrm{l})$, pyruvic acid $(175 \mathrm{mg} / \mathrm{l})$, ribose $(750 \mathrm{mg} / \mathrm{l})$, allopurinol $(13.5 \mathrm{mg} / \mathrm{l})$ and $\mathrm{NaH}_{2} \mathrm{PO}_{4}(200 \mathrm{mg} / \mathrm{l})$, was used during the initial $5 \mathrm{~min}$ of perfusion to remove $\mathrm{Ca}^{2+}$ and blood from the tissue. After addition of $\mathrm{NaHCO}_{3}(1.3 \mathrm{~g} / \mathrm{l})$, the $\mathrm{pH}$ of this perfusate was 7.0 when gassed with carbogen. Cell dispersion was performed for $30 \mathrm{~min}$ in the same solution containing also collagenase (660 mg/l, Worthington Cls-1), bovine albumin (2 g/l) and $\mathrm{CaCl}_{2}(50 \mu \mathrm{M})$. During the isolation procedure the solutions were gassed with carbogen and the temperature was maintained at $37^{\circ} \mathrm{C}$. The cells were rod shaped and showed clear striation when the external calcium was restored. Before use, the cells were stored overnight at $14^{\circ} \mathrm{C}$ in modified JMM solution (pH 7.4). 
Action potentials were recorded from $\mathrm{Ca}^{2+}$-tolerant canine ventricular cells superfused with modified Krebs solution containing: $120 \mathrm{mM} \mathrm{NaCl}, 5.4 \mathrm{mM} \mathrm{KCl}, 2.7 \mathrm{mM} \mathrm{CaCl}_{2}$, $1.1 \mathrm{mM} \mathrm{MgCl}_{2}, 1.1 \mathrm{mM} \mathrm{NaH}_{2} \mathrm{PO}_{4}, 24 \mathrm{mM} \mathrm{NaHCO}_{3}$ and $6 \mathrm{mM}$ glucose. The solution was equilibrated with carbogen at a temperature of $37^{\circ} \mathrm{C}$ and the $\mathrm{pH}$ was adjusted to 7.4. Transmembrane potentials were recorded using glass microelectrodes filled with $3 \mathrm{M} \mathrm{KCl}$ and having tip resistance between 20 and $40 \mathrm{M} \Omega$. These electrodes were connected to the input of an Axoclamp-2B amplifier (Axon Instruments). The cells were continuously paced through the recording electrode at a steady cycle length of $1000 \mathrm{~ms}$ using $1 \mathrm{~ms}$ wide rectangular current pulses with $120 \%$ threshold amplitude. Action potentials were digitized at $100 \mathrm{kHz}$ using Digidata 1200 A/D card (Axon Instruments) and stored for later analysis.

$\mathrm{Ca}^{2+}$ current was recorded from cells superfused with oxygenated Tyrode solution containing $140 \mathrm{mM} \mathrm{NaCl}, 5.4 \mathrm{mM}$ $\mathrm{KCl}, 2.5 \mathrm{mM} \mathrm{CaCl}_{2}, 1.2 \mathrm{mM} \mathrm{MgCl} 2,0.35 \mathrm{mM} \mathrm{Na}_{2} \mathrm{HPO}_{4}, 5 \mathrm{mM}$ HEPES, $10 \mathrm{mM}$ glucose and $3 \mathrm{mM}$ 4-aminopyridine, at $\mathrm{pH}$ 7.4. Suction pipettes, fabricated from borosilicate glass, had tip resistance of $2 \mathrm{M} \Omega$ after filling with pipette solution composed of $110 \mathrm{mM} \mathrm{KCl}, 40 \mathrm{mM} \mathrm{KOH}, 10 \mathrm{mM}$ HEPES, $10 \mathrm{mM}$ EGTA, $20 \mathrm{mM}$ TEACl, $3 \mathrm{mM}$ K-ATP and $0.25 \mathrm{mM}$ GTP. The $\mathrm{pH}$ of this solution was adjusted to 7.2 with $\mathrm{KOH}$. Membrane currents were recorded with an Axopatch-1D amplifier (Axon Instruments) using the whole cell configuration of the patch clamp technique. After establishing high (1-10 G $\Omega$ ) resistance seal by gentle suction, the cell membrane beneath the tip of the electrode was disrupted by further suction or by applying $1.5 \mathrm{~V}$ electrical pulses for 1-5 ms. The series resistance was typically 4-8 M $\Omega$ before compensation (usually 50-80\%). Experiments were discarded when the series resistance was high or substantially increasing during the measurement. Outputs from the clamp amplifier were digitized at $20 \mathrm{kHz}$ using an A/D converter (Digidata 1200, Axon Instruments) under software control (pClamp 6.0, Axon Instruments). $\mathrm{Ca}^{2+}$ current was measured at a rate of $0.2 \mathrm{~Hz}$ using depolarizing voltage pulses of $400 \mathrm{~ms}$ duration clamped to $0 \mathrm{mV}$ from the holding potential of $-40 \mathrm{mV}$. In cardiac cells fluoxetine was added to the bath in a cumulative manner, applying each concentration for $2 \mathrm{~min}$. This period of time was sufficient to achieve steady-state effects in both action potential and ion current measurements.

Study of anticonvulsant effect of fluoxetine in mouse epilepsy model. Mice of either sex, weighing $30 \pm 1.2 \mathrm{~g}$, were injected with pentylenetetrazole $(100 \mathrm{mg} / \mathrm{kg}$, s.c.) in order to evoke epileptic activity. Single doses of $10 \mathrm{mg} / \mathrm{kg}$ fluoxetine (racemic, $\mathrm{S}(+)$, or $\mathrm{R}(-)$ enantiomer) were administered subcutaneously either 30 or $60 \mathrm{~min}$ before the application of pentylenetetrazole. Seizure activity was evaluated continuously during the period of $60 \mathrm{~min}$ following the injection of pentylenetetrazole according to the following parameters. Survival rate (expressed as percentage) was defined as the number of animals surviving the 60 -min post-pentylenetetrazole period divided by the total number animals exposed to pentylenetetrazole in any particular group. Seizure latency represents time elapsed from the pentylenetetrazole-injection to the first appearance of seizures. Survival duration was calculated only for those animals which failed to survive the critical 60 -min period of evaluation.
Statistics. All values presented are arithmetic means \pm SEM. Statistical significance was determined by using Student's t-test performed following ANOVA. Differences were considered significant when the P-value was $<0.05$.

The entire investigation conforms with the Guide for the Care and Use of Laboratory Animals published by the US National Institutes of Health (NIH publication no. 85-23, revised 1996) and with the principles outlined in the Declaration of Helsinki.

\section{Results}

Effect of fluoxetine on $\mathrm{Ba}^{2+}$ current in rat cochlear neurons. To measure $\mathrm{Ba}^{2+}$ current flowing through $\mathrm{Ca}^{2+}$ channels, voltage ramps rising from $-100 \mathrm{mV}$ to $40 \mathrm{mV}$ during $200 \mathrm{~ms}$ were applied. These ramps were repeated at a rate of $0.33 \mathrm{~Hz}$, the holding potential between the ramps was $-75 \mathrm{mV}$. The activation of $\mathrm{Ca}^{2+}$ channels during the ramps was seen as an inward current mediated by $\mathrm{Ba}$ ions. The effect of fluoxetine was measured as a reduction of the peak inward current. Fluoxetine was applied in a non-cumulative manner. The cell was exposed to one concentration of the drug (either $\mathrm{S}(+)$, $\mathrm{R}(-)$, or the racemic form) for 20-30 sec using a fast flow system. This time was sufficient to achieve steady-state effect. Exposures were separated with 5-min periods of washout. The next exposure (to another form of the same concentration) was applied only after full reversion of the drug-effect. All three forms of fluoxetine suppressed peak $\mathrm{Ba}^{2+}$ current in a concentration-dependent manner studied between concentrations of 0.1 and $100 \mu \mathrm{M}$, the concentrationresponse curve obtained for racemic fluoxetine is shown in Fig. 1A. Fitting these results to the Hill equation yielded a $\mathrm{K}_{\mathrm{d}}$ value of $22.3 \pm 3.5 \mu \mathrm{M}$ and Hill coefficient of $0.87 \pm 0.1 \quad(n=5)$. Significant differences between the two enantiomers were observed only at a concentration of $5 \mu \mathrm{M}$, where $\mathrm{R}(-)$ fluoxetine caused $28 \pm 3 \%$ decrease in the current in contrast to the $18 \pm 2 \%$ reduction observed with $5 \mu \mathrm{M} \mathrm{S}(-)$-fluoxetine $(\mathrm{P}<0.05, \mathrm{n}=13)$ (Fig. 1B). The effect of fluoxetine was fully reversible even at the highest applied concentration of $100 \mu \mathrm{M}$ (Fig. 1C), where the current was largely suppressed by the drug. One hundred $\mu \mathrm{M}$ of $\mathrm{S}(+), \mathrm{R}(-)$ and racemic fluoxetine caused comparable, $81 \pm 3 \%, 76 \pm 2 \%$ and $80 \pm 4 \%$ block, respectively. Fluoxetine appeared to cause a certain degree of desensitization, as its blocking effect decreased with time. This desensitization was extremely rapid, it was over within a few seconds after exposure to the drug (Fig. 1D). This desensitization was prominent at low concentrations $(0.1-1 \mu \mathrm{M})$, but it was never observed with $100 \mu \mathrm{M}$ fluoxetine.

Effect of fluoxetine enantiomers on action potential configuration and L-type $\mathrm{Ca}^{2+}$ current in isolated canine ventricular myocytes. Results obtained with racemic fluoxetine were reported earlier (8), therefore, the effects of the $\mathrm{S}(+)$ and $\mathrm{R}(-)$ enantiomers were studied and compared in these experiments. Fluoxetine $(0.1-10 \mu \mathrm{M})$ shortened action potential duration (both $\mathrm{APD}_{50}$ and $\mathrm{APD}_{90}$ ) in a concentration-dependent manner (Table I). This effect was associated with depression of the plateau potential at $10 \mu \mathrm{M}$ concentration. Concentrations higher than $10 \mu \mathrm{M}$ caused progressive depolarization and loss of excitability, therefore, the effects of these concentrations 

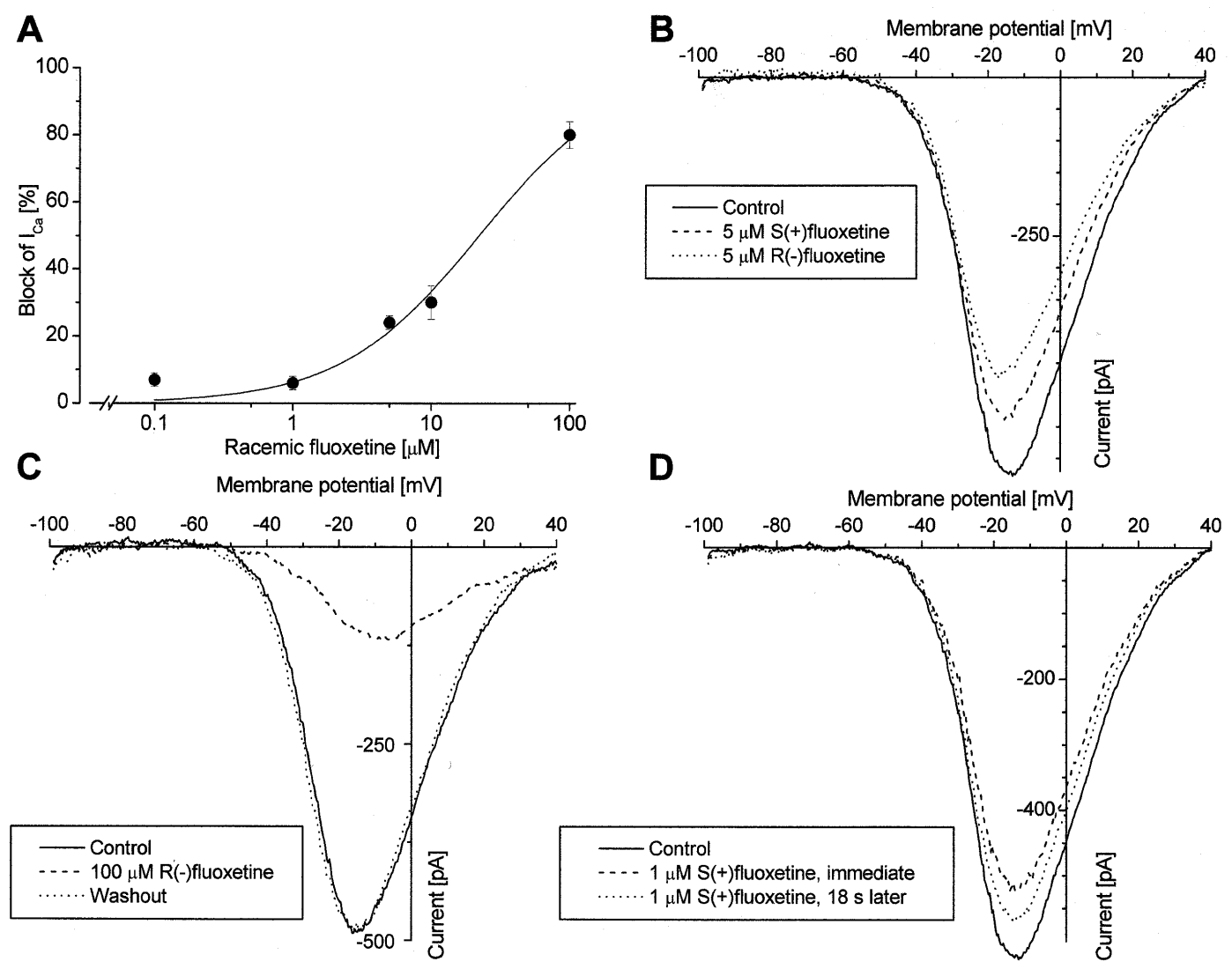

D

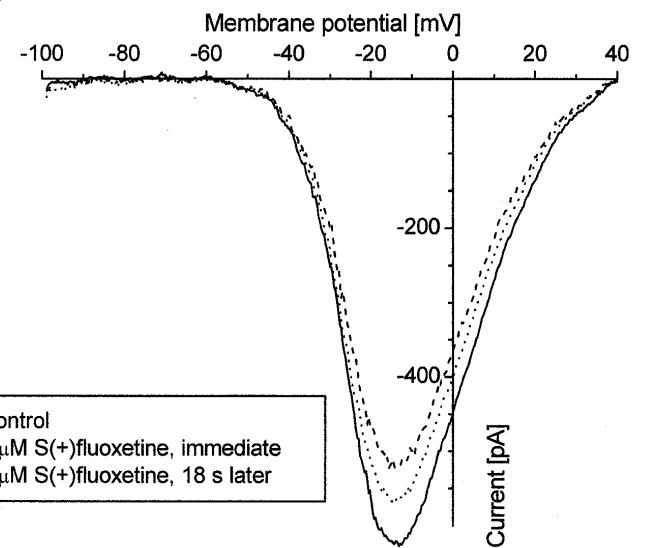

Figure 1. Effect of fluoxetine on the calcium channels of pyramidal neurons isolated from the dorsal cochlear nucleus of the rat. (A), Concentration-dependent effect of fluoxetine on peak $\mathrm{Ba}^{2+}$ current. Effects were evaluated after reaching steady-state level of inhibition (within 20-30 sec). Symbols and bars represent mean \pm SEM values, $n=5$. The blocking effect was statistically significant at each concentration comparing to control (not indicated). (B), Differential effects of $5 \mu \mathrm{M} \mathrm{S}(+)$-fluoxetine and $\mathrm{R}(-)$-fluoxetine on the $\mathrm{Ba}^{2+}$ current. After taking the control trace, $5 \mu \mathrm{M} \mathrm{S}(+)$-fluoxetine was applied first, and after reaching steady-state effect $(20 \mathrm{sec})$ the cell was superfused with $5 \mu \mathrm{M} \mathrm{R}(-)$-fluoxetine for further $20 \mathrm{sec}$. (C), Reversibility of the effect of fluoxetine. The cell was treated with $100 \mu \mathrm{M} \mathrm{R}(-)$-fluoxetine for $25 \mathrm{sec}$, then washed with fluoxetine-free medium for $5 \mathrm{~min}$. (D), Desensitization observed with $1 \mu \mathrm{M}$ fluoxetine. After taking control record, $1 \mu \mathrm{M} \mathrm{S}(+)$-fluoxetine was applied. The first subsequent trace (dashed line) was taken immediately ( 3 sec) after application of fluoxetine, dotted line indicates the trace taken after reaching the steady-state effect at $18 \mathrm{sec}$.

Table I. Effects of R(-)-fluoxetine and S(+)-fluoxetine on action potential characteristics in isolated canine ventricular myocytes.

\begin{tabular}{lcccc}
\hline & $\mathrm{APD}_{50}(\mathrm{~ms})$ & $\mathrm{APD}_{90}(\mathrm{~ms})$ & $\mathrm{APA}(\mathrm{mV})$ & $\mathrm{V}_{\max }(\mathrm{V} / \mathrm{s})$ \\
\hline $\mathrm{R}(-)$-fluoxetine $(\mathrm{n}=5)$ & & & & \\
$\quad$ Control & $157 \pm 5$ & $216 \pm 7$ & $117.9 \pm 1.5$ & $313 \pm 5$ \\
Fluoxetine $0.1 \mu \mathrm{M}$ & $150 \pm 4$ & $209 \pm 4$ & $118.1 \pm 1.4$ & $314 \pm 6$ \\
Fluoxetine $1 \mu \mathrm{M}$ & $134 \pm 7^{\mathrm{a}, \mathrm{b}}$ & $202 \pm 4^{\mathrm{b}}$ & $115.8 \pm 1.7$ & $284 \pm 26$ \\
Fluoxetine $3 \mu \mathrm{M}$ & $98 \pm 9^{\mathrm{a}, \mathrm{b}}$ & $175 \pm 7^{\mathrm{a}, \mathrm{b}}$ & $115.1 \pm 1.6$ & $276 \pm 29$ \\
Fluoxetine $10 \mu \mathrm{M}$ & $64 \pm 3^{\mathrm{a}}$ & $154 \pm 10^{\mathrm{a}}$ & $108.7 \pm 1.3^{\mathrm{a}}$ & $229 \pm 24^{\mathrm{a}}$ \\
Washout & $157 \pm 7$ & $224 \pm 10$ & $115.8 \pm 2.0$ & $290 \pm 31$ \\
$\mathrm{~S}+$-fluoxetine $(\mathrm{n}=5)$ & & & \\
Control & $170 \pm 12$ & $236 \pm 11$ & $117.9 \pm 2.2$ & $316 \pm 7$ \\
Fluoxetine $0.1 \mu \mathrm{M}$ & $156 \pm 12^{\mathrm{a}}$ & $223 \pm 10^{\mathrm{a}}$ & $118.1 \pm 2.2$ & $314 \pm 11$ \\
Fluoxetine $1 \mu \mathrm{M}$ & $115 \pm 10^{\mathrm{a}, \mathrm{b}}$ & $192 \pm 10^{\mathrm{a}, \mathrm{b}}$ & $117.1 \pm 2.3$ & $295 \pm 25$ \\
Fluoxetine $3 \mu \mathrm{M}$ & $82 \pm 8^{\mathrm{a}, \mathrm{b}}$ & $162 \pm 6^{\mathrm{a}, \mathrm{b}}$ & $117.0 \pm 2.1$ & $231 \pm 26^{\mathrm{a}}$ \\
Fluoxetine $10 \mu \mathrm{M}$ & $69 \pm 9^{\mathrm{a}}$ & $154 \pm 5^{\mathrm{a}}$ & $108.7 \pm 3.6^{\mathrm{a}}$ & $305 \pm 16$ \\
Washout & $147 \pm 10^{\mathrm{a}}$ & $233 \pm 9$ & $117.9 \pm 2.4$ & \\
\hline
\end{tabular}

$\mathrm{APD}_{50}$ and $\mathrm{APD}_{90}$ action potential duration measured at 50 and $90 \%$ repolarization, respectively. APA, action potential amplitude; $\mathrm{V}_{\text {max }}$,

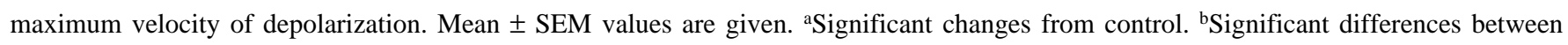
effects of $\mathrm{R}(-)$-fluoxetine and $\mathrm{S}(+)$-fluoxetine $(\mathrm{P}<0.05)$. 
A
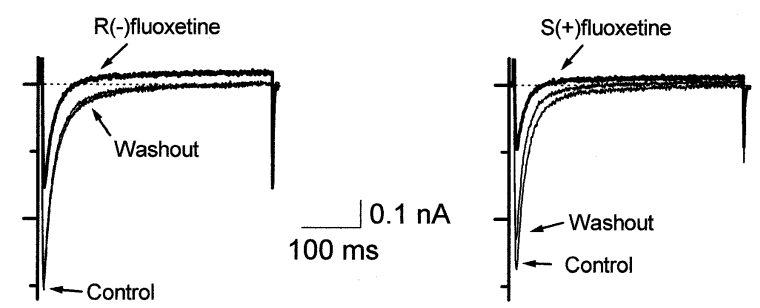

B
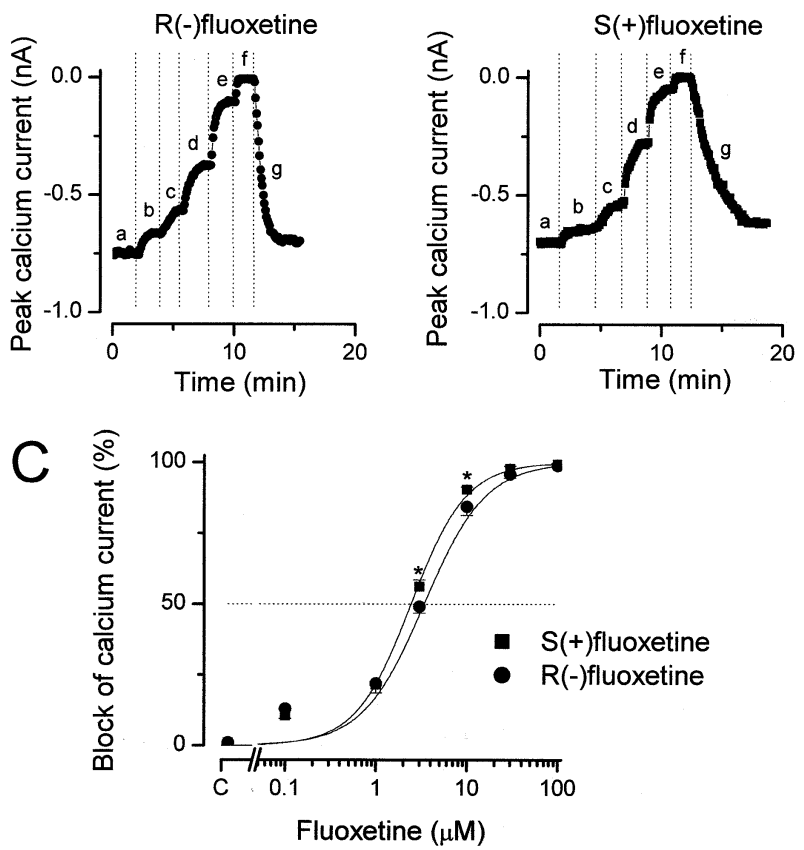

Figure 2. Effect of the $\mathrm{R}(-)$ and $\mathrm{S}(+)$ enantiomer of fluoxetine on the $\mathrm{Ca}^{2+}$ current in canine ventricular cardiomyocytes. (A), Superimposed $\mathrm{I}_{\mathrm{Ca}}$ records obtained before, during ( $2 \mathrm{~min}$ ), and after superfusion with $3 \mu \mathrm{M}$ fluoxetine. Washout lasted for $5 \mathrm{~min}$. Currents were measured during step depolarizations to $0 \mathrm{mV}$, each lasting for $400 \mathrm{~ms}$, applied from the holding potential of $-40 \mathrm{mV}$ at a rate of $0.2 \mathrm{~Hz}$. (B), Representative record showing the time scale of development and reversion of the fluoxetine-induced changes in $\mathrm{I}_{\mathrm{Ca}}$. The drug was applied in a cumulative manner (a, control; b, 0.1; c, 1; d, 3; e, 10; f, $30 \mu \mathrm{M}$ fluoxetine, each concentration for $2 \mathrm{~min}, \mathrm{~g}: 5 \mathrm{~min}$ washout). (C), Cumulative concentration-response curve obtained with the $\mathrm{S}(+)$ and $\mathrm{R}(-)$ enantiomers of fluoxetine in canine ventricular myocytes $(n=5$ for each). The solid line was generated by fitting data to the Hill equation. Symbols and bars represent mean values \pm SEM, asterisks indicate significant differences $(\mathrm{P}<0.05)$ between the effects of the two enantiomers.

were not analyzed. Significant differences in the APDshortening effect was observed between the $\mathrm{S}(+)$ and $\mathrm{R}(-)$ enantiomer of fluoxetine: $\mathrm{S}(+)$-fluoxetine shortened $\mathrm{APD}_{50}$ significantly from $0.1 \mu \mathrm{M}$, while $\mathrm{R}(-)$-fluoxetine only from $1 \mu \mathrm{M}$. Furthermore, the magnitude of shortening was significantly greater with 1 and $3 \mu \mathrm{M}$ of $\mathrm{S}(+)$-fluoxetine than with the $\mathrm{R}(-)$ enantiomer. At $10 \mu \mathrm{M}$ concentration, however, no significant differences were observed between the effects of the two enantiomers on action potential duration. At this concentration both enantiomers also depressed action potential upstroke: reduction of maximum velocity of depolarization $\left(\mathrm{V}_{\max }\right)$ and action potential amplitude (APA) was observed. In this respect no differences were seen between the enantiomers. All these effects of fluoxetine developed rapidly (within $2 \mathrm{~min}$ ) and were fully reversible within the 5-min period of washout (except the $\mathrm{APD}_{50}$ value following $10 \mu \mathrm{M}$ of $\mathrm{S}(+)$-fluoxetine).

In voltage clamped canine ventricular myocytes both enantiomers of fluoxetine ( $\mathrm{n}=5$ for each) caused concentrationdependent block of the peak $\mathrm{Ca}^{2+}$ current measured at $0 \mathrm{mV}$ (Fig. 2). Reduction in the amplitude of the peak current was not accompanied with changes in the time course of inactivation (Fig. 2A). Similarly to the effects on action potentials, the suppressive effect of fluoxetine on $\mathrm{I}_{\mathrm{Ca}}$ developed rapidly and was largely reversible (Fig. 2B). The concentrationresponse curve, presented in Fig. 2C, shows that both enantiomers inhibited $\mathrm{I}_{\mathrm{Ca}}$ significantly from the lowest $(0.1 \mu \mathrm{M})$ concentration studied, having moderate differences in the $\mathrm{K}_{\mathrm{d}}$ values $(2.4 \pm 0.1$ and $2.8 \pm 0.2 \mu \mathrm{M})$ and Hill coefficients (1.41 \pm 0.05 and $1.24 \pm 0.13$ ) obtained for the $S(+)$ and $R(-)$ enantiomer, respectively. Significant differences in the blocking effect was observed only at 3 and $10 \mu \mathrm{M}$ concentrations: $\mathrm{S}(+)$-fluoxetine caused a higher degree of block than $\mathrm{R}(-)$ fluoxetine $(56.3 \pm 2.2 \%$ versus $49.1 \pm 2.2 \%$ and $95.5 \pm 0.9 \%$ versus $84.5 \pm 3.1 \%$ block with 3 and $10 \mu \mathrm{M} \mathrm{S}(+)$ and $\mathrm{R}(-)-$ fluoxetine, respectively, $\mathrm{P}<0.05, \mathrm{n}=5$ ). The current was fully abolished by $100 \mu \mathrm{M}$ fluoxetine. In summary, cardiac preparations appear to be more sensitive to the $S(+)$ than the $\mathrm{R}(-)$ enantiomer, as indicated by the stronger effect of the former at 1-3 $\mu \mathrm{M}$ concentrations on action potential duration and at 3-10 $\mu \mathrm{M}$ concentrations on $\mathrm{I}_{\mathrm{Ca}}$. In both cases the effect of the $\mathrm{R}(-)$ enantiomer was more readily reversible than that of the $\mathrm{S}(+)$ enantiomer (Table I and Fig. 2A and B).

Anticonvulsant effect of fluoxetine in pentylenetetrazole-treated mice. From the 32 control animals (exposed to $100 \mathrm{mg} / \mathrm{kg}$ pentylenetetrazole alone) 31 died within the subsequent $60 \mathrm{~min}$ of evaluation (3.1\% survival rate). Pretreatment with $10 \mathrm{mg} / \mathrm{kg}$ fluoxetine $30 \mathrm{~min}$ before application of pentylenetetrazole increased the rate of survival, however, this increase was highly variable according to the fluoxetine enantiomer applied. Pretreatment with $10 \mathrm{mg} / \mathrm{kg}$ racemic or $\mathrm{S}(+)$-fluoxetine produced an increase of $8.9 \%$ for both groups, in contrast to the $33 \%$ increase observed with the R(-) enantiomer. These differences were much less pronounced when fluoxetine was applied $60 \mathrm{~min}$ prior to the injection of pentylenetetrazole (Fig. 3A). The protective effect of $5 \mathrm{mg} / \mathrm{kg}$ fluoxetine (applied $60 \mathrm{~min}$ before pentylenetetrazole) on the rate of survival was negligible: only 1 animal survived in the $\mathrm{R}(-)$ and none in the $\mathrm{S}(+)$-fluoxetine group (out of 12 and 13, respectively, not shown in Fig. 3).

Survival duration, monitored within the period of $60 \mathrm{~min}$ following the injection of pentylenetetrazole, was increased significantly by pretreatment with either $10 \mathrm{mg} / \mathrm{kg}$ racemic or the same concentration of R(-)-fluoxetine, whereas the protective effect was not significant in the case of the $\mathrm{S}(+)$ enantiomer (Fig. 3B). Interestingly, this parameter appeared to be insensitive to the time of fluoxetine-treatment, since the values were almost identical in the cases of 30 and $60 \mathrm{~min}$ pretreatment. Survival duration was also longer with $5 \mathrm{mg} / \mathrm{kg}$ $\mathrm{R}(-)$ than $\mathrm{S}(+)$-fluoxetine (15.3 \pm 4 versus $8.8 \pm 1.8$ min survivals were observed, $n=12$ and $n=13$, respectively, not shown). Qualitatively similar increase in seizure latency was obtained with: $10 \mathrm{mg} / \mathrm{kg}$ racemic or $\mathrm{R}(-)$-fluoxetine, but not the $\mathrm{S}(+)$ enantiomer (Fig. 3C). 

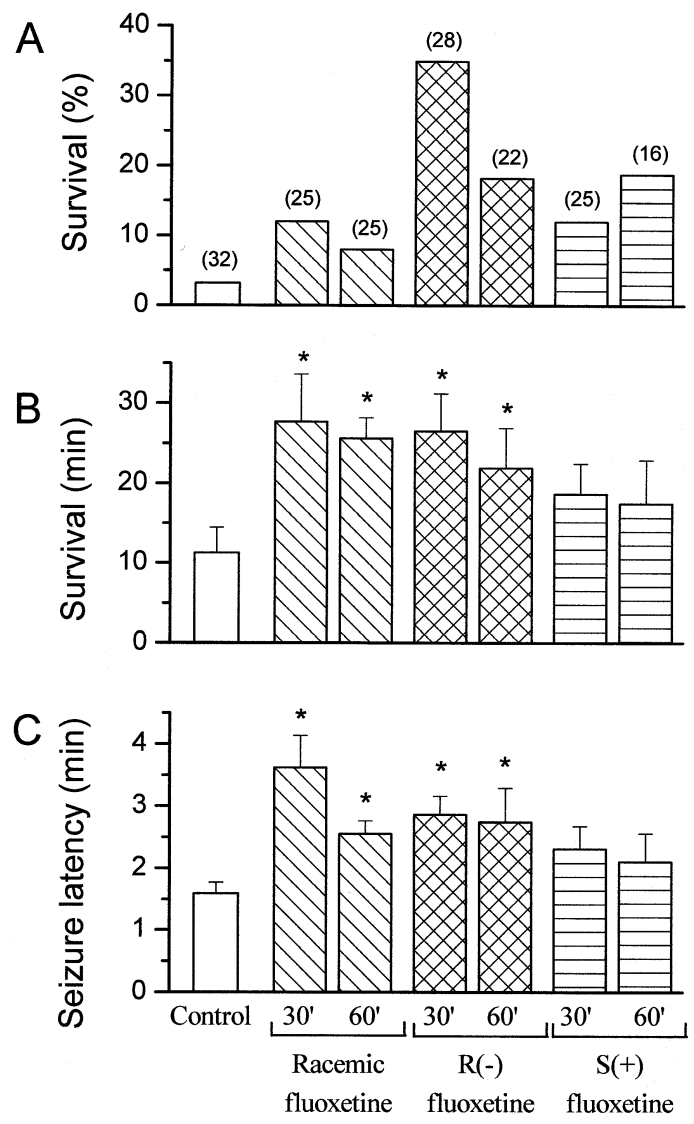

Figure 3. Anticonvulsant effect of the fluoxetine enantiomers in pentylenetetrazole treated mice. Single doses of fluoxetine $(\mathrm{S}(+), \mathrm{R}(-)$ or racemic, $10 \mathrm{mg} /$ $\mathrm{kg}$ ) were administered either 30 or $60 \mathrm{~min}$ before the application of pentylenetetrazole $(100 \mathrm{mg} / \mathrm{kg})$. (A), Rate of survival, expressed as percentage, was defined as the number of animals surviving the 60 -min post-pentylenetetrazole period divided by the total number animals exposed to pentylenetetrazole in any particular group (indicated in parentheses). (B), Average survival duration. Only those animals which failed to survive the critical 60 -min period of evaluation were included. (C), Seizure latency represents time elapsed from the pentylenetetrazole-injection to the first appearance of seizures. Columns and bars represent mean \pm SEM values, asterisks indicate significant differences $(\mathrm{P}<0.05)$ comparing to the pentylenetetrazole-treated (control) group.

\section{Discussion}

Anticonvulsant action of fluoxetine. Our present results indicate that fluoxetine exerts an anticonvulsant action in the pentylentetrazole-induced seizure model. These data are in accordance with those of previous studies demonstrating an anticonvulsant effect of fluoxetine in other models of epilepsy. Fluoxetine was found to be effective against maximal electroshock-induced tonic extension in rats (44), audiogen seizures in mice and rats $(21,25)$, and focally evoked limbic motor seizures in rats (22). Several clinical observations and animal studies showed that fluoxetine enhanced the anticonvulsant potency of various antiepileptic drugs (19,20,45-47). Regarding the effective anticonvulsant dose of the drug, fluoxetine exerted $50 \%$ protective effect at $5 \mathrm{mg} / \mathrm{kg}$ in the limbic motor seizure model, whereas, in the genetically epilepsy-prone rats (GEPR-9) the $\mathrm{ED}_{50}$ was $\sim 16 \mathrm{mg} / \mathrm{kg}$. In our present seizure model fluoxetine showed a significant anticonvulsant action at the dose of $10 \mathrm{mg} / \mathrm{kg}$. We found a marked difference in the anticonvulsant activity of the two enantiomers, since R(-)-fluoxetine was more potent to increase the survival rate than the $S(+)$ enantiomer. The time-course of anticonvulsant action of racemic and R(-)-fluoxetine was also different. Racemic fluoxetine exhibited equal anticonvulsant activity applied either 30 or 60 min before the pentylentetrazole-injection, while R(-)-fluoxetine had stronger anticonvulsant action when applied $30 \mathrm{~min}$ before the convulsant drug. The opposite was observed with the $\mathrm{S}(+)$ enantiomer. These observations can be well explained by recent results indicating considerable differences in the pharmacokinetic properties of the two enantiomers of fluoxetine (39-41). S(+)-fluoxetine was found to be more slowly eliminated than the R(-) enantiomer, and it was suggested that its $\mathrm{N}$-demethyl metabolite, $\mathrm{S}(+)$-norfluoxetine is more potent than $\mathrm{R}(-)$-norfluoxetine. Both metabolites may accumulate on chronic treatment with racemic fluoxetine (40).

In spite of previous data reporting that serotonin is involved in regulation of seizure susceptibility $(44,48-50)$, it seems unlikely that inhibition of serotonin reuptake is the only mechanism by which fluoxetine exerts its anticonvulsant effect. Fluoxetine was shown to suppress the high $\mathrm{K}^{+}$-induced burst firing in rat hippocampal neurons (10) considered as a model for epilepsy not involving serotonergic transmission (51). Thus the other possible explanation for the anticonvulsant action of fluoxetine may be related to its inhibitory effect on ionic channels. Several reports indicated that altered activity of voltage-gated $\mathrm{Na}^{+}$and $\mathrm{Ca}^{2+}$ channels was involved in the enhancement of neuronal discharges during epilepsy (51-53), and conventional anticonvulsant drugs were found to block voltage-dependent $\mathrm{Na}^{+}$and $\mathrm{Ca}^{2+}$ channels $(11,13,14,53)$. Our previous results demonstrating that fluoxetine was a considerably more potent inhibitor of $\mathrm{Ca}^{2+}$ than $\mathrm{Na}^{+}$channels support the possibility that inhibition of $\mathrm{Ca}^{2+}$ channels by fluoxetine may contribute to its anticonvulsant action (10).

Effects on calcium channels. In the present study we have compared the actions of racemic, $\mathrm{R}(-)$ and $\mathrm{S}(+)$-fluoxetine on calcium channels in isolated rat cochlear neurons and canine ventricular myocytes. We have shown that fluoxetine decreased the high-voltage activated neuronal $\mathrm{Ca}^{2+}$ current (mainly L-type) in a concentration-dependent manner, and at a concentration of $5 \mu \mathrm{M}$ this effect of R(-)-fluoxetine was significantly greater than that of the $\mathrm{S}(+)$ enantiomer. In our experiments, performed in cohlear neurons, the $\mathrm{IC}_{50}$ for suppression of $\mathrm{I}_{\mathrm{Ca}}$ was $22.3 \mu \mathrm{M}$ suggesting that the sensitivity of these neurons to fluoxetine is lower than that was seen in hippocampal cells (10). On the other hand, blocking potency on $\mathrm{I}_{\mathrm{Ca}}$, comparable to our results, were obtained in PC12 cells $\left(\mathrm{IC}_{50}=13 \mu \mathrm{M}\right)(54)$ and in synaptosomes (for inhibition of calcium uptake, $\left.\mathrm{IC}_{50}=27 \mu \mathrm{M}\right)(55)$. The discrepancy between the $\mathrm{IC}_{50}$ values may likely be attributed to differences in the dominant $\mathrm{Ca}^{2+}$ channel type in the neurons examined.

The lower range of fluoxetine concentrations $(0.1-5 \mu \mathrm{M})$ blocking neuronal $\mathrm{Ca}^{2+}$ current in this study overlaps the therapeutic plasma concentrations $(0.15-1.5 \mu \mathrm{M})$ of the drug. Under certain conditions (e.g. in case of drug interactions or reduced metabolism in elderly) the plasma concentration of fluoxetine can reach even higher levels. Moreover, during chronic treatment fluoxetine was shown to accumulate in human brain twenty times higher than its plasma level $(56,57)$. 
Thus, a significant inhibition of $\mathrm{Ca}^{2+}$ channels by fluoxetine may occur in a patient chronically treated with fluoxetine, exerting its anticonvulsant or antimigraine activity.

In isolated canine cardiomyocytes both enantiomers shortened action potential duration, but the effectivity of the two enantiomers was different. S(+)-fluoxetine shortened $\mathrm{APD}_{50}$ significantly from the concentration of $0.1 \mu \mathrm{M}$, while $\mathrm{R}(-)$-fluoxetine from $1 \mu \mathrm{M}$ only. In addition, the magnitude of shortening was also significantly greater in the case of 1 and $3 \mu \mathrm{M}$ of $\mathrm{S}(+)$-fluoxetine. At the higher concentration of $10 \mu \mathrm{M}$ both enantiomers decreased also action potential amplitude and the maximum rate of depolarization. No difference was observed between the two enantiomers from this point of view indicating an equal potency of blocking cardiac $\mathrm{Na}^{+}$channels. The shortening effect of fluoxetine on cardiac action potentials may be best explained with inhibition of the L-type $\mathrm{Ca}^{2+}$ channel. Indeed, both enantiomers blocked peak $\mathrm{Ca}^{2+}$ current significantly, however, this effect was more pronounced at 3 and $10 \mu \mathrm{M}$ concentrations of the $\mathrm{S}(+)$ than the $\mathrm{R}(-)$ enantiomer. The 2.4 and $2.8 \mu \mathrm{M} \mathrm{K} \mathrm{K}_{\mathrm{d}}$ values, obtained for $\mathrm{S}(+)$ and $\mathrm{R}(-)$-fluoxetine in this study, is very close to the value of $3 \mu \mathrm{M}$, reported previously by Pacher et al (8) with racemic fluoxetine in canine ventricular cells. These cardiac electrophysiological actions of fluoxetine enantiomers may be proarrhythmic due to impairment of atrioventricular or intraventricular conduction and shortening of repolarization. Moreover, the negative inotropic action observed in rat papillary muscle (8) and the vasodilator effect of racemic fluoxetine (58) may also be due to inhibition of L-type $\mathrm{Ca}^{2+}$ channels and may explain the cardiovascular side-effects (dysrhythmias, syncope) observed occasionally in patients treated with fluoxetine $(26,27,29,30,32-34,36,38)$.

In conclusion, our present data indicate that the two enantiomers of fluoxetine have different anticonvulsant effects and inhibitory activities on neuronal and cardiac $\mathrm{Ca}^{2+}$ channels at micromolar concentrations. While $\mathrm{R}(-)$-fluoxetine exerts stronger anticonvulsant action associated with inhibition of neuronal $\mathrm{Ca}^{2+}$ channels, the $\mathrm{S}(+)$ form appears to be more potent in shortening of cardiac action potential due to inhibition of cardiac $\mathrm{Ca}^{2+}$ channels. It is important to emphasize that these differences in the action of the two enantiomers on $\mathrm{Ca}^{2+}$ current were evident only within a narrow range of concentrations $(3-10 \mu \mathrm{M})$ and were not great in magnitude. It is tempting to speculate, however, that the $\mathrm{S}(+)$ isomer may be more responsible for the undesired cardiovascular side-effects that sometimes develop during chronic fluoxetine treatment. Used as an antidepressant or anticonvulsant drug, less severe cardiac side-effects are anticipated with R(-)fluoxetine.

\section{Acknowledgements}

This study was sponsored by grants from the Hungarian Research Foundation (OTKA-T026577, OTKA-T29624, OTKA-T031824), Hungarian Ministry of Health (ETT-244/ 2000, ETT-49/2000, 03-155/2000) and Hungarian Ministry of Education (FKFP-0243/2000). The authors thank Professor Elemér Fogarassy, József Bálint and Professor Péter Mátyus for the preparation of optically pure fluoxetine enantiomers and Zsolt Bagi for the statistical analysis.

\section{References}

1. Hennings EC, Kiss JP and Vizi ES: Nicotinic aetylcholine receptor antagonist effect of fluoxetine in rat hippocampal slices. Brain Res 759: 292-294, 1997.

2. Colunga GJ, Awad JN and Miledi R: Blockage of muscle and neuronal nicotinic acetylcholine receptors by fluoxetine (Prozac). Proc Natl Acad Sci USA 94: 2041-2044, 1997.

3. Maertens C, Wei L, Voets T, Droogmans G and Nilius B: Block by fluoxetine of volume-regulated anion channels. $\mathrm{Br} \mathrm{J}$ Pharmacol 126: 508-514, 1999.

4. Farrugia G: Modulation of ionic currents in isolated canine and human jejunal circular smooth muscle cells by fluoxetine. Gastroenterology 110: 1438-1445, 1996.

5. Pancrazio JJ, Kamatchi GL, Roscoe AK and Lynch C: Inhibition of neuronal $\mathrm{Na}^{+}$channels by antidepressant drugs. J Pharmacol Exp Ther 284: 208-214, 1998.

6. Tytgat J, Maertens C and Daenens P: Effect of fluoxetine on a neuronal, voltage-dependent potassium channel (Kv1.1). Br J Pharmacol 122: 1417-1424, 1997.

7. Rae JL, Rich A, Zamudio AC and Candia OA: Effect of Prozac on whole cell ionic currents in lens and corneal epithelia. Am J Physiol 269: C250-C256, 1995.

8. Pacher P, Magyar J, Szigligeti P, et al: Electrophysiological effects of fluoxetine in mammalian cardiac tissues. Naunyn Schmiedebergs Arch Pharmacol 361: 67-73, 2000.

9. Stauderman KA, Gandhi VC and Jones DJ: Fluoxetine-induced inhibition of synaptosomal $\left({ }^{3} \mathrm{H}\right) 5-\mathrm{HT}$ release: possible $\mathrm{Ca}^{2+}$ channel inhibition. Life Sci 50: 2125-2138, 1992.

10. Deák F, Lasztóczi B, Pacher P, Petheö GL, Kecskeméti V and Spät A: Inhibition of voltage-gated calcium channels by fluoxetine in rat hippocampal pyramidal cells. Neuropharmacology 39: 1029-1036, 2000.

11. McLean MJ and MacDonald RL: Multiple actions of phenytoin on mouse spinal cord neurons in cell culture. J Pharmacol Exp Ther 227: 779-789, 1983.

12. Schirrmacher K, Mayer A, Walden J, Dusing R and Bingmann D: Effects of carbamazepine on action potential and calcium currents in spinal ganglion cells in vitro. Neuropsychobiology 27: 1276-1279, 1993.

13. Stefani A, Spadoni F and Bernardi G: Voltage-activated calcium channels: targets of antiepileptic drug therapy? Epilepsia 38: 959-965, 1997.

14. Von Wegerer J, Hesslinger B, Berger M and Walden J: A calcium antagonistic effect of the new antiepileptic drug lamotrigine. Eur J Neuropsychopharmacol 2: 77-81, 1997.

15. Forscher W: Antiepileptic effect of calcium antagonists. Drugs Today 24 (Suppl 3): 167-174, 1988.

16. Meyer FB, Anderson TS and Sundt TS: Anticonvulsant properties of dihydropyridine calcium antagonists. Drugs Today 24 (Suppl 3): 175-186, 1988.

17. Aicardi G and Schwartzkroin PA: Suppression of epileptiform burst discharges in CA3 neurons of rat hippocampal slices by the organic calcium channel blocker verapamil. Exp Brain Res 81: 288-296, 1990.

18. Zapater P, Javaloy J, Roman JF, Vidal MT and Horga JF: Anticonvulsant effects of nimodipine and two novel dihydropyridines (PCA 50922 and PCA 50941) against seizures elicited by pentylentetrazole and electroconvulsive shock in mice. Brain Res 796: 311-314, 1998.

19. Leander JD: Fluoxetine, a selective serotonin-uptake inhibitor, enhances anticonvulsant effects of phenytoin, carbamazepine and ameltolide (LY 201116). Epilepsia 33: 573-576, 1992.

20. Kecskeméti V, Pacher P, Deák F, Bagi Z, Petheö GL and Spät A: Anticonvulsant effects of fluoxetine. Brain Res Bull 53S: 35, 2000.

21. Sparks DL and Buckholtz NS: Combined inhibition of serotonin uptake and oxidative diamination attenuates audiogenic seizures in DBA/2J mice. Pharmacol Biochem Behav 23: 753-757, 1985.

22. Prendiville $\mathrm{S}$ and Gale K: Anticonvulsant effect of fluoxetine on focally evoked limbic motor seizures in rats. Epilepsia 34: 381-384, 1993.

23. Wada Y, Shiraishi J, Nakamura M and Hasegawa H: Prolonged but not acute fluoxetine administration produces its inhibitory effect on hippocampal seizures in rats. Psychopharmacology 118: 305-309, 1995.

24. Favale E, Rubino V, Mainardi P, Lunardi G and Albano C: Anticonvulsant effect of fluoxetine in humans. Neurology 45: 1926-1927, 1995. 
25. Dailey JW, Yan QS, Adams-Curtis LE, Ryu JR, Ko KH, Mishra PK and Jobe PC: Neurochemical correlates of antiepileptic drugs in the genetically epilepsy-prone rat (GEPR). Life Sci 58: 259-266, 1996.

26. Buff DD, Brenner R, Kirtane SS and Gilboa R: Dysrhythmia associated with fluoxetine treatment in elderly patients with cardiac disease. J Clin Psychiatry 52: 174-176, 1991.

27. Friedman EH: Fluoxetine-induced bradycardia. J Clin Psychiatry 52: 427, 1991

28. Masquelier I, Saint JO, Bourdiol MC, Boiffin A and Bouchon JP: Bradycardia and hypothermia in an elderly patient receiving fluoxetine. Presse Med 22: 553, 1993.

29. Drake WM and Gordon GD: Heart block in a patient on propranolol and fluoxetine. Lancet 343: 425-426, 1994.

30. Hussein S and Kaufman BM: Bradycardia associated with fluoxetine in an elderly patient with sick sinus syndrome. Postgrad Med J 70: 56, 1994.

31. Roberge RJ and Martin TG: Mixed fluoxetine loxapine overdose and atrial flutter. Ann Emerg Med 23: 586-590, 1994.

32. Graudins A, Vossler C and Wang R: Fluoxetine-induced cardiotoxicity with response to bicarbonate therapy. Am J Emerg Med 15: 501-503, 1997.

33. Anderson $\mathbf{J}$ and Compton SA: Fluoxetine induced bradycardia in presenile dementia. Ulster Med J 66: 144-145, 1997.

34. Ellison JM, Milofsky JE and Ely E: Fluoxetine-induced bradycardia and syncope in two patients. J Clin Psychiatry 51: 385-386, 1990.

35. McAnally LE, Threlkeld KR and Dreyling CA: Case report of a syncopal episode associated with fluoxetine. Ann Pharmacother 26: 1090-1091, 1992.

36. Cherin P, Colvez A, Deville DE, Periere G and Sereni D: Risk of syncope in the elderly and consumption of drugs: a casecontrol study. J Clin Epidemiol 50: 313-320, 1997.

37. Livshits ATL and Danenberg HD: Tachycardia, orthostatic hypotension and profound weakness due to concomitant use of fluoxetine and nifedipine. Pharmacopsychiatry 30: 274-275, 1997.

38. Rich JM, Njo L, Roberts KW and Smith KP: Unusual hypotension and bradycardia in a patient receiving fenfluramine, phentermine and fluoxetine. Anesthesiology 88: 529$531,1998$.

39. Agranat I and Caner H: Intellectual property and chirality of drugs. Drug Dis Today 4: 313-321, 1999.

40. Lane RM and Baker GB: Chirality and drugs used in psychiatry: nice to know or need to know? Cell Mol Neurobiol 19: 355-372, 1999.

41. Tucker GT: Chiral switches. Lancet 355: 1085-1087, 2000.

42. Harasztosi C, Forsythe ID, Szûcs G, Stanfield PR and Rusznák Z: Possible modulatory role of voltage-activated $\mathrm{Ca}^{2+}$ currents determining the membrane properties of isolated pyramidal neurones of the rat dorsal cochlear nucleus. Brain Res 839: 109-119, 1999.

43. Magyar J, Bányász T, Szigligeti P, Körtvély Á, Jednákovits A and Nánási PP: Electrophysiological effects of bimoclomol in canine ventricular myocytes. Naunyn Schmiedebergs Arch Pharmacol 361: 303-310, 2000 .
44. Buterbaugh GG: Effect of drugs modifying central serotonergic function on the response of extensor and non-extensor rats to maximal electroshock. Life Sci 23: 2393-2404, 1978.

45. Raju SS, Noor AR, Gurthu S, Giriyappanavar CR, Acharys SB, Low HC and Quah SH: Effect of fluoxetine on maximal electroshock seizures in mice: acute vs chronic administration. Pharmacol Res 39: 451-454, 1999.

46. Pisani F, Spina E and Oteri G: Antidepressant drugs and seizure susceptibility: from in vitro data to clinical practice. Epilepsia 40: S48-S56, 1990.

47. Monaco $\mathrm{F}$ and Cicolin A: Interactions between anticonvulsant and psychoactive drugs. Epilepsia 40: S71-S76, 1999.

48. Jobe PC, Dailey JW and Reigel CE: Noradrenergic and serotonergic determinants of seizure susceptibility and severity in genetically-prone rats. Life Sci 39: 775-782, 1986.

49. Browning RA, Wood AV, Merrill MA, Dailey JW and Jobe PC: Enhancement of the anticonvulsant effect of fluoxetine following blockade of 5-HT $1 \mathrm{~A}$ receptors. Eur J Pharmacol 336: 1-6, 1997.

50. Pasini A, Tortorrella A and Gale K: The anticonvulsant action of fluoxetine in substantia nigra is dependent upon endogenous serotonin. Brain Res 724: 84-88, 1996.

51. McNamara JO: Cellular and molecular basis of epilepsy. J Neurosci 14: 3413-3425, 1994.

52. Speckmann EJ, Straub H and Kohling R: Contribution of calcium ions to the generation of epileptic activity and antiepileptic calcium antagonism. Neuropsychobiology 17: 122-127, 1993.

53. MacDonald RL and Kelly KM: Mechanisms of action of currently prescribed and newly developed antiepileptic drugs. Epilepsia 35S: 41-50, 1994.

54. Hahn SJ, Choi JS, Rhie DJ, Oh CS, Jo YH and Kim MS: Inhibition by fluoxetine of voltage-activated ion channels in rat PC12 cells. Eur J Pharmacol 367: 113-118, 1999.

55. Lavoie PA, Beauchamp G and Elie R: Atypical antidepressants inhibit depolarization-induced calcium uptake in rat hippocampus synaptosomes. Can J Physiol Pharmacol 75: 983-987, 1997.

56. Karson CN, Newton JE, Livingstone R, Jolly JB, Cooper TB, Sprigg $\mathbf{J}$ and Komoroski RA: Human brain fluoxetine concentrations. J Neuropsychiatry Clin Neurosci 5: 322-329, 1993.

57. Komoroski RA, Newton JE, Cardwell D, Prigg J, Pearce J and Karson CN: In vivo $19 \mathrm{~F}$ spin relaxation and localized spectroscopy of fluoxetine in human brain. Magn Reson Med 31: 204-211, 1994.

58. Pacher P, Ungvári Z, Kecskeméti V and Koller Á: Serotonin reuptake inhibitor, fluoxetine, dilates skeletal muscle arterioles. Possible role of altered $\mathrm{Ca}^{2+}$ sensitivity. Br J Pharmacol 127: 740-746, 1999. 